\title{
INFLUENZA VIRUSES IN ADULT DOGS RAISED IN RURAL AND URBAN AREAS IN THE STATE OF SÃO PAULO, BRAZIL
}

Dalva Assunção Portari MANCINI(1), Rita Maria Zucatelli MENDONÇA(1), Aparecida Santo Pietro PEREIRA(1), Adélia Hiroko Nagamori KAWAMOTO(1), Camila Infantosi VANNUCCHI(2), José Ricardo PINTO(1), Enio MORI(3) \& Jorge MANCINI FILHO(4)

\begin{abstract}
SUMMARY
In 1970, searching for the interspecies transmission of influenza viruses led to the first study on influenza viruses in domestic animals. Birds and mammals, including human beings, are their natural hosts; however, other animals may also play a role in the virus epidemiology. The objective was to investigate the incidence of influenza viruses in adult dogs raised in rural $(9,19.56 \%)$ and urban $(37,80.43 \%)$ areas in the state of São Paulo, Brazil. Dog serum samples were examined for antibodies to influenza viruses by the hemagglutination inhibition (HI) test using the corresponding antigens from the circulating viruses in Brazil. Dogs from rural areas presented antibodies to influenza $\mathrm{A} \mathrm{H}_{3} \mathrm{~N}_{2}$, and influenza $\mathrm{A} \mathrm{H}_{7} \mathrm{~N}_{7}$ and $\mathrm{H}_{3} \mathrm{~N}_{8}$. In rural areas, dog sera displayed mean titers as 94.37, 227.88, 168.14, $189.62 \mathrm{HIU} / 25 \mu \mathrm{L}$ for subtypes $\mathrm{H}_{1} \mathrm{~N}_{1}, \mathrm{H}_{3} \mathrm{~N}_{2}, \mathrm{H}_{7} \mathrm{~N}_{7}, \mathrm{H}_{3} \mathrm{~N}_{8}$, respectively. About $84 \%$ and $92 \%$ of dogs from urban areas exhibited antibodies to human influenza $\mathrm{A} \mathrm{H}_{1} \mathrm{~N}_{1}$ and $\mathrm{H}_{3} \mathrm{~N}_{2}$, respectively, with statistical difference at $p<0.05$ between the mean titers of antibodies to $\mathrm{H}_{1} \mathrm{~N}_{1}$ and $\mathrm{H}_{3} \mathrm{~N}_{2}$. About $92 \%$ and $100 \%$ were positive for $\mathrm{H}_{7} \mathrm{~N}_{7}$ and $\mathrm{H}_{3} \mathrm{~N}_{8}$, respectively. In dogs from urban areas, the mean titers of antibodies against influenza $\mathrm{A} \mathrm{H}_{1} \mathrm{~N}_{1}, \mathrm{H}_{3} \mathrm{~N}_{2}, \mathrm{H}_{7} \mathrm{~N}_{7}$ and $\mathrm{H}_{3} \mathrm{~N}_{8}$, were 213.96, 179.42, 231.76, 231.35 HIU/25 $\mu \mathrm{L}$ respectively. The difference among them was not statistically significant at $p>0.05$. In conclusion, these dogs were positive for both human and equine influenza viruses. The present study suggests the first evidence that influenza viruses circulate among dogs in Brazil.
\end{abstract}

KEYWORDS: Influenza A; Dogs; Serology; Epidemiology.

\section{INTRODUCTION}

Influenza is an acute and highly contagious viral disease that afflicts the respiratory tract and is transmitted through contact with nasopharyngeal secretions. It is known to be caused by RNA viruses of the Orthomyxoviridae family. In their lipoprotein envelope are two glycoproteins, hemagglutinin $(\mathrm{H})$ and /neuraminidase $(\mathrm{N})$, whose structures differ among virus strains. Sixteen hemagglutinin (H1 - H16) and nine neuraminidase (N1 - N9) subtypes have been identified in influenza A viruses. Influenza A viruses can infect both humans and animals, but influenza B viruses only infect humans ${ }^{1,17}$.

Hemagglutinin $(\mathrm{H})$ and neuraminidase $(\mathrm{N})$ undergo considerable antigenic variation in influenza $A$ and $B$ viruses, whereas these same proteins display minor alterations in types B and C. Such changes lead to the emergence of new strains. Influenza incidence peaks during winter and can be very recurrent. The main symptoms are: high temperature $\left( \pm 38^{\circ} \mathrm{C}\right)$, sneezing- and coughing, which can evolve into pneumonia in both humans and animals. Influenza types $\mathrm{A}$ and $\mathrm{B}$ are responsible for seasonal flu epidemics. Type $\mathrm{C}$ also causes the disease; however, the symptoms are milder ${ }^{10}$.
Influenza virus receptors on host cells differ among mammalian species, viruses bind to receptors on tracheal epithelial cells, while duck viruses attach to the cells of the intestine. Avian $\left(\mathrm{H}_{1}, \mathrm{H}_{3}, \mathrm{H}_{9}\right.$, $\left.\mathrm{H}_{11}\right)$ and equine $\left(\mathrm{H}_{3}\right.$ and $\left.\mathrm{H}_{7}\right)$ strains have receptor-binding specificity for acetylneuraminic acid with an alpha 2,3-N-linkage to galactose $\left(\alpha-2,3\right.$ NeuAcGal). Human strains $\left(\mathrm{H}_{1}\right.$ and $\left.\mathrm{H}_{3}\right)$, on the other hand, have specificity for the alpha 2,6-linkage. Pigs present both receptors, which makes them susceptible to human and avian influenza viruses. They are considered to be intermediate hosts for the adaptation of avian influenza viruses to humans and "mixing vessels" for novel combinations between avian and human influenza viruses, which can result in the emergence of new pandemic strains. The resulting new viruses may then be able to infect horses and humans ${ }^{13}$. The proteolytic cleavage of the viral receptor proteins is also a very important activation mechanism in the pathogenesis of influenza viruses ${ }^{18,20}$.

The host range of influenza viruses has been widely studied in order to characterize the role of some animals in the transmission chain - once considered unlikely to infect others. The susceptibility of domestic animals to an influenza type A virus was first reported in $1972^{12}$. Recently, influenza viruses were isolated from dogs with respiratory 
MANCINI, D.A.P.; MENDONÇA, R.M.Z.; PEREIRA, A.S.P.; KAWAMOTO, A.H.N.; VANNUCCHI, C.I.; PINTO, J.R.; MORI, E. \& MANCINI FILHO, J. - Influenza viruses in adult dogs raised in rural and urban areas in the state of São Paulo, Brazil. Rev. Inst. Med. Trop. Sao Paulo, 54(6); 311-4, 2012.

infections. Among the isolated viruses, a specific strain, named Influenza A/canine/Florida/43/2004, was observed to be very closely related to the equine influenza A subtype $\mathrm{H}_{3} \mathrm{~N}_{8}$. This monophyletic origin of US canine influenza viruses of subtype $\mathrm{H}_{3} \mathrm{~N}_{8}$, which have circulated among dogs since the early 1990 s, very likely indicates a single trans-species transmission event directly from horse to dog, possibly facilitated by direct contact in a racing environment ${ }^{3,15}$.

Dog-to-dog contact transmission of avian-origin influenza A viruses subtypes $\mathrm{H}_{3} \mathrm{~N}_{2}$ and $\mathrm{H}_{3} \mathrm{~N}_{8}$ has been observed in a recent experimental study of Beagle dogs. The dogs showed clinical signs after 14 days postinoculation, confirming the interspecies transmission of the influenza virus ${ }^{16}$. Domestic animals (cats and dogs) may also enable the adaptation of avian influenza viruses to mammalians, especially carnivores that feed on infected birds 5 .

Recently, HEINEMANN et al. ${ }^{6}$ reported serologic evidence of the equine influenza virus A subtype $\mathrm{H}_{7} \mathrm{~N}_{7}$ circulation in some regions of north Brazil.

Reptilian and crocodilian species, as well as domestic animals (cats and dogs), can be potential hosts of influenza viruses. Recently, influenza type A viruses were detected in crocodilians from two locations in Florida (USA) $)^{2}$

In one of our previous studies, poisonous snakes (heterothermic animals) showed seropositivity for human influenza A viruses subtypes $\mathrm{H}_{1} \mathrm{~N}_{1}$ and $\mathrm{H}_{3} \mathrm{~N}_{2}{ }^{9}$.

To date, no studies on influenza viruses in dogs have been carried out in Brazil.

\section{OBJECTIVE}

This work was fueled by concerns about the dog-to-human contact transmission of influenza viruses. Therefore this work aimed to study the role of adult dogs from rural and urban areas in the state of São Paulo, Brazil, in the epidemiology of the influenza virus infections. Considering the originality of the present study, the hope is that it could contribute towards the research and the knowledge of this study field.

\section{MATERIALS AND METHODS}

Animals: Forty-six healthy dogs, assisted at the clinic of the Faculty of Veterinary Medicine at the University of São Paulo - Brazil, were grouped according to whether they were raised in nine rural or 37 urban areas in the state of São Paulo. The protocol for animal studies, CEEA number 2230/2011, was approved by the Animal Experimentation Ethics Committee of the School of Veterinary and Animal Sciences of the University of São Paulo.

Serum: Blood serum samples were taken, inactivated by heat treatment at $56{ }^{\circ} \mathrm{C}$ for $30 \mathrm{~min}$ and then treated with Kaolin (20\%) and erythrocytes $(50 \%)$ according to MANCINI et al. ${ }^{8}$, DESHPANDE et $a l .{ }^{4}$ and OIEN et al. ${ }^{11}$.

Serology: The hemagglutination inhibition (HI) test was performed according to MANCINI et al. ${ }^{8}$. Four HA units in $25 \mu \mathrm{L}$ of viruses were used. Titers were expressed as hemagglutination inhibition units per 25 $\mu \mathrm{L}$ of sera $(\mathrm{HIU} / 25 \mu \mathrm{L})$.

Antigens: Antigens of the influenza viruses as A/SP/2/95 = A/ Beijing/353/89 $\left(\mathrm{H}_{3} \mathrm{~N}_{2}\right), \mathrm{A} / \mathrm{SP} / 1 / 91=\mathrm{A} /$ Singapore/6/86 $\left(\mathrm{H}_{1} \mathrm{~N}_{1}\right), \mathrm{A} / \mathrm{Eq} 1 /$ $\mathrm{SP} / 56\left(\mathrm{~A} \mathrm{Eq} 1 \mathrm{H}_{7} \mathrm{~N}_{7}\right.$ ) and A/Eq2/1/SP/85 (A Eq2 $\mathrm{H}_{3} \mathrm{~N}_{8}$ ) were used. Influenza virus samples were grown in MDCK (Madin Darby canine kidney) cell cultures according to MANCINI et al. ${ }^{8}$.

\section{RESULTS}

The serological analysis was obtained through the hemagglutination inhibition (HI) test which showed that $15.27,6.52$ and $6.52 \%$ of the dogs exhibited low antibody titers $(\leq 40 \mathrm{HIU} / 25 \mu \mathrm{L})$ to influenza A viruses subtypes $\mathrm{H}_{1} \mathrm{~N}_{1}, \mathrm{H}_{3} \mathrm{~N}_{2}$ and $\mathrm{H}_{7} \mathrm{~N}_{7}$, suggesting no protective response against these subtypes. The other animals tested presented higher antibody titers, ranging from 40 to $\geq 320 \mathrm{HIU} / 25 \mu \mathrm{L}$ (Table 1 ).

Many serologic methods such as the neutralization, Elisa, could be used to search the antibodies to influenza virus. But the hemagglutination inhibition test is usually the choice for investigating the influenza virus ${ }^{13,14}$.

As seen in Figure 1, the average number of protective antibody titers ( $\geq 40 \mathrm{HIU} / 25 \mu \mathrm{L}$ ) to human $\mathrm{H}_{1} \mathrm{~N}_{1}$ and $\mathrm{H}_{3} \mathrm{~N}_{2}$ and equine influenza $\mathrm{H}_{7} \mathrm{~N}_{7}$, $\mathrm{H}_{3} \mathrm{~N}_{8}$, in rural areas were $94.37,227.88,168.14,189.62 \mathrm{HIU} / 25 \mu \mathrm{L}$, respectively. In this case, the difference $(p<0.05)$ among mean titers for human influenza A subtypes $\mathrm{H}_{1} \mathrm{~N}_{1}$ and $\mathrm{H}_{3} \mathrm{~N}_{2}$ was statistically significant.

Figure 2 shows the average of protective antibody titers $(\geq 40 \mathrm{HIU} / 25 \mu \mathrm{L})$ against human and equine influenza viruses in dogs

Table 1

Analysis of antibody titers for influenza A virus subtypes in dog sera from urban and rural areas. Values expressed as HIU/25 $\mu \mathrm{L}$

\begin{tabular}{lcccccc}
\hline \multirow{2}{*}{$\begin{array}{l}\text { Virus } \\
\text { Subtypes }\end{array}$} & \multicolumn{5}{c}{ HIU/25 $\mu \mathrm{L}$} \\
\cline { 2 - 6 } & $07(15.217 \%)$ & $07(15.271 \%)$ & $16(34.782 \%)$ & $09(19.565 \%)$ & $07(15.217 \%)$ & $(100 \%)$ \\
\hline $\mathrm{H}_{1} \mathrm{~N}_{1}$ & $03(6.521 \%)$ & $13(28.260 \%)$ & $08(17.391 \%)$ & $15(32.608 \%)$ & $07(15.217 \%)$ & $(100 \%)$ \\
$\mathrm{H}_{3} \mathrm{~N}_{2}$ & - & $08(17.391 \%)$ & $14(30.434 \%)$ & $17(36.956 \%)$ & $07(15.217 \%)$ & $(100 \%)$ \\
$\mathrm{H}_{3} \mathrm{~N}_{8}$ & $03(6.521 \%)$ & $08(17.391 \%)$ & $10(21.739 \%)$ & $22(47.826 \%)$ & $03(6.521 \%)$ & $(100 \%)$ \\
$\mathrm{H}_{7} \mathrm{~N}_{7}$ & & & & & & \multicolumn{5}{c}{ Total } & \\
\hline
\end{tabular}

(HIU = Hemagglutination inhibition units). 


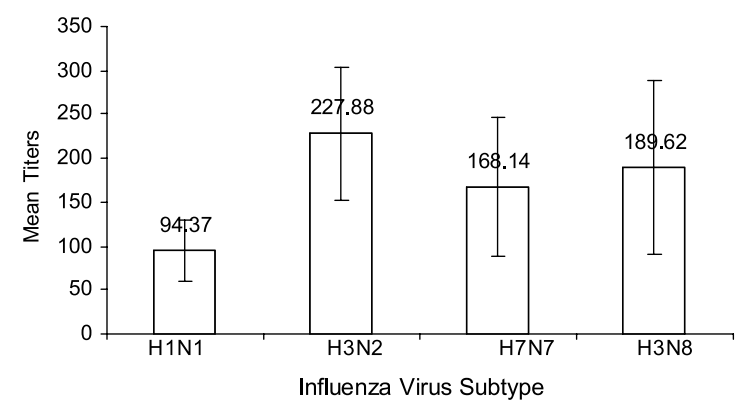

H1N1XH3N2 $P<0.05$

Fig. 1 - Analysis of mean titers of protective antibodies ( $\geq 40 \mathrm{HIU} / 25 \mu \mathrm{L})$ for human and equine influenza A virus subtypes in dogs from rural areas.

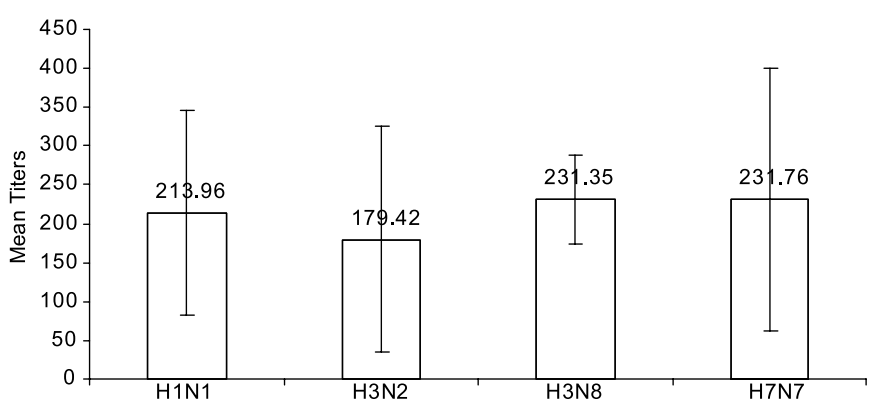

Influenza Virus Subtype

Statistical difference is not significant $P>0.05$

Fig. 2 - Analysis of mean titers of protective antibodies ( $\geq 40 \mathrm{HIU} / 25 \mu \mathrm{L}$ ) for human and equine influenza A virus subtypes in dogs from urban areas.

from urban areas. Mean titers of 213.96, 179.42, 231.76 and 231.35 HIU/25 $\mu \mathrm{L}$ were observed for human influenza A subtypes $\mathrm{H}_{1} \mathrm{~N}_{1}$ and $\mathrm{H}_{3} \mathrm{~N}_{2}$ and equine influenza A subtypes $\mathrm{H}_{7} \mathrm{~N}_{7}$ and $\mathrm{H}_{3} \mathrm{~N}_{8}$ viruses, respectively. No statistically significant difference among mean titers was observed $(p>0.05)$. When dogs from urban and rural areas were compared for the presence of protective antibody titers $(\geq 40 \mathrm{HIU} / 25 \mu \mathrm{L})$ against human and equine influenza A subtypes $\mathrm{H}_{1} \mathrm{~N}_{1}, \mathrm{H}_{3} \mathrm{~N}_{2}, \mathrm{H}_{7} \mathrm{~N}_{7}$ and $\mathrm{H}_{3} \mathrm{~N}_{8}$, no statistically significant difference $(p>0.05)$ was observed (Fig 3 ).

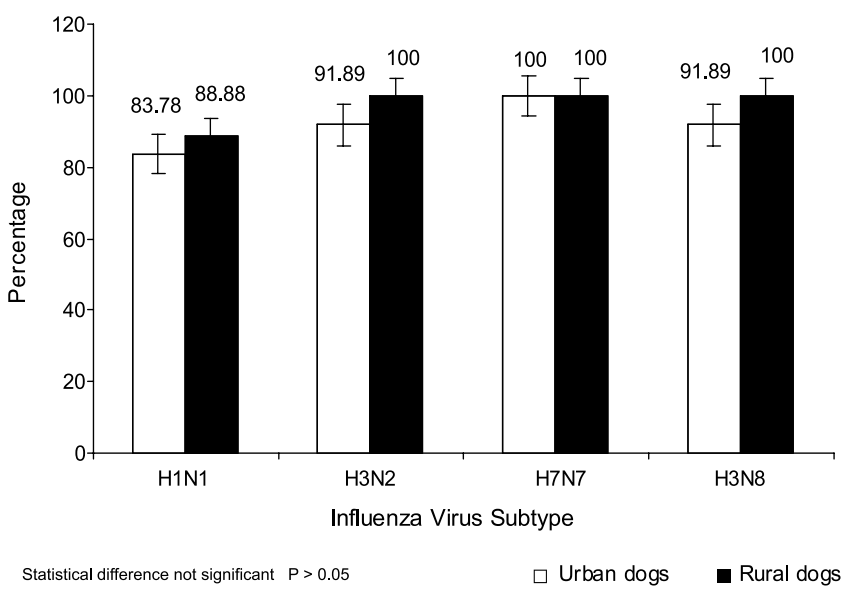

Fig. 3 - Comparative analysis of percentages of dogs from urban versus rural areas exhibiting protective antibody titers ( $\geq 40 \mathrm{HIU} / 25 \mu \mathrm{L}$ ) for human and equine influenza A virus subtypes.

\section{DISCUSSION}

Nine $(19.56 \%)$ and $37(80.43 \%)$ dogs from rural and urban areas, respectively, exhibited high mean titers of antibodies ( $\geq 40 \mathrm{HIU} / 25 \mu \mathrm{L})$ against influenza $A$ viruses subtypes $\mathrm{H}_{1} \mathrm{~N}_{1}, \mathrm{H}_{3} \mathrm{~N}_{2}, \mathrm{H}_{7} \mathrm{~N}_{7}$ and $\mathrm{H}_{3} \mathrm{~N}_{8}$, suggesting that these dogs had been in contact with human and equine influenza viruses. Our results are in agreement with a recent serological study performed via the hemagglutination inhibition test on pet dogs participating in a flyball tournament in Pennsylvania (PA, USA), which showed positive results for antibodies against an influenza A virus subtype $\mathrm{H}_{3} \mathrm{~N}_{8}{ }^{14}$.

Healthy dogs, kept in close contact with equine influenza virus (EIV)-infected horses, were reported as developing antibodies against the virus, which suggests that interspecies transmission of EIV to dogs could have occurred as result of contact between these animal species ${ }^{19}$.

Similar observations were also reported for dogs in Japan. Their serum samples responded positively to human and equine influenza A viruses subtype $\mathrm{H}_{3}$ in the hemagglutination inhibition test $(\mathrm{HI})^{13}$.

A careful analysis of acute and convalescent dog serum samples, history and clinical signs are important in diagnosing canine influenza. In a study on the etiology of the disease, its causative agent, a type A virus, was found to be closely related to the equine influenza A virus subtype $\mathrm{H}_{3} \mathrm{~N}_{8}{ }^{7}$.

Results from this study and the literature suggest evidence that dogs can harbor the influenza viruses and may play a role in the interspecies transmission and epidemiology of the virus. Furthermore, recent studies on the distribution of receptor molecules in the canine respiratory tract detected that $\mathrm{SA} \alpha 2,3 \mathrm{Gal}$ was the dominant receptor, although $\mathrm{SA} \alpha 2,6 \mathrm{Gal}$ could be detected in the trachea, bronchi and bronchioles. These reports are consistent with the hypothesis that the sero-positive dogs found in this study were infected with $\mathrm{H}_{3} \mathrm{~N}_{2}$ influenza A virus originating from human sources ${ }^{13}$.

The high percentage (100\%) of the protective antibodies to influenza virus detected in all evaluated dogs from rural and urban areas suggests that animals have had several contacts with different virus subtypes, during their lives. The subtype $\mathrm{H}_{7} \mathrm{~N}_{7}$, considered the original avian strain revealed to be present in the dogs population. Also, HEINEMANN et al. (2009) reported that the influenza A, subtype $\mathrm{H}_{7} \mathrm{~N}_{7}$, was present in equine populations raised in north from Brazil ${ }^{6}$.

It's also possible to conclude that influenza viruses could be circulating among dogs in many parts of the world, including Brazil.

\section{RESUMO}

\section{Incidência do vírus influenza em cães adultos criados em áreas rural e urbana do estado de São Paulo, Brasil}

A transmissão interespecífica do vírus influenza é relatada em estudo sobre influenza com animais domésticos desde 1970. Pássaros e mamíferos, incluindo o homem, são seus hospedeiros naturais, porém outros animais podem participar da sua epidemiologia. Foi investigada a incidência do vírus influenza em cães adultos criados em zonas rural 
MANCINI, D.A.P.; MENDONÇA, R.M.Z.; PEREIRA, A.S.P.; KAWAMOTO, A.H.N.; VANNUCCHI, C.I.; PINTO, J.R.; MORI, E. \& MANCINI FILHO, J. - Influenza viruses in adult dogs raised in rural and urban areas in the state of São Paulo, Brazil. Rev. Inst. Med. Trop. Sao Paulo, 54(6); 311-4, 2012.

(9, 19,56\%) e urbana (37, 80,43\%), do Estado de São Paulo. Os soros dos cães foram examinados pelo teste de inibição da hemaglutinação (IH), usando antígeno dos vírus influenza circulantes no Brasil. Nos cães rurais foram detectados títulos médios de 94,37, 227,88, 168,14 e $189,62 \mathrm{UIH} / 25 \mu \mathrm{L}$ (unidades inibidoras de hemaglutinação/25 $\mu \mathrm{L}$ ) para os subtipos $\mathrm{H}_{1} \mathrm{~N}_{1}, \mathrm{H}_{3} \mathrm{~N}_{2}, \mathrm{H}_{7} \mathrm{~N}_{7}, \mathrm{H}_{3} \mathrm{~N}_{8}$ de vírus influenza $\mathrm{A}$, respectivamente, com diferenças estatisticamente significativas $(\mathrm{p}<0,05)$ entre as médias de títulos de anticorpos contra $\mathrm{H}_{1} \mathrm{~N}_{1}$ e $\mathrm{H}_{3} \mathrm{~N}_{2}$. Cerca de $84 \%$ e $92 \%$ dos cães urbanos responderam aos vírus influenza A humano $\mathrm{H}_{1} \mathrm{~N}_{1}$ e $\mathrm{H}_{3} \mathrm{~N}_{2}$, respectivamente e destes $92 \%$ e $100 \%$ foram positivos para os vírus eqüinos $\mathrm{H}_{7} \mathrm{~N}_{7}$ e $\mathrm{H}_{3} \mathrm{~N}_{8}$, respectivamente. Para esses cães as médias de títulos de anticorpos para os vírus influenza $\mathrm{A} \mathrm{H}_{1} \mathrm{~N}_{1}, \mathrm{H}_{3} \mathrm{~N}_{2}, \mathrm{H}_{7} \mathrm{~N}_{7}$ e $\mathrm{H}_{3} \mathrm{~N}_{8}$ foram 213,96, 179,42, 231,76 e 231,35UIH/25 $\mu \mathrm{L}$, respectivamente. As diferenças entre as médias não foram estatisticamente significativas ( $\mathrm{p}>0,05)$. Conclui-se que os cães apresentaram positividade para ambos vírus influenza humano e equino. O presente estudo sugere, pela primeira vez, evidências de que há circulação do vírus influenza em cães, no Brasil.

\section{ACKNOWLEDGEMENTS}

The authors thank Conselho Nacional de Desenvolvimento Científico e Tecnológico for their financial support(CNPq Project 471876/2009/2010).

\section{REFERENCES}

1. Alexander DJ, Brown IH. Recent zoonoses caused by influenza A viruses. Rev Sci Tech. 2000;19:197-225.

2. Davis LM, Spackman E. Do crocodilians get the flu? Looking for influenza A in captive crocodilians. J Exp Zool A Ecol Genet Physiol. 2008;309:571-80.

3. Crawford PC, Dubovi EJ, Castleman WL, Stephenson I, Gibbs EP, Chen I, et al. Transmission of equine influenza virus to dogs. Science. 2005;310:482-5.

4. Deshpande M, Abdelmagid O, Tubbs A, Jayappa H, Wasmoen T. Experimental reproduction of canine influenza virus H3N8 infection in young puppies. Vet Ther. 2009;10:29-39.

5. Harder TC, Wahlenkamp TW. Influenza virus infections in dogs and cats. Vet Immunol Immunopathol. 2010;134:54-60.

6. Heinemann MB, Cortez A, Lara MCCSH, Cunha EMS, Nassar AFC, Villalobos EMC, et al. Soroprevalência do vírus da influenza equina no Município de Uruará, PA, Brasil, Amazônia Oriental. Arq Inst Biol. 2009;76:697-9.
7. Hilling K, Hanel R. Canine influenza. Compend Contin Educ Vet. 2010;32(6):E1-9.

8. Mancini DAP, Mendonça RMZ, Cianciarullo AM, Kobashi LS, Trindade HG, Fernandes W. et al. Influenza em animais heterotérmicos. Rev Soc Bras Med Trop. 2004;37:204-9.

9. Mancini DAP, Mendonça RMZ, Kawamoto AHN, Giorgetti M, Trindade HG, Fernandes $\mathrm{W}$, et al. Identification and characterization of influenza virus isolated from Brazilian snakes. In: Méndes-Villas A, editor. Communicating current research and educational topics and trends in applied microbiology. Badajoz: Formatex Microbiology Series No. 1; 2007. p. 868-74.

10. Neumann G, Kawaoka Y. Host range restriction and pathogenicity in the context of influenza pandemic. Emerg Infect Dis. 2006;12:881-6.

11. Oien N, Mattern S, Brozowski J, Teel J, Salmon S. Cross-reactivity to field isolates of canine influenza virus by a killed canine influenza virus (H3N8, Iowa05) vaccine. Int J Appl Res Vet Med. 2012;10:14-8.

12. Paniker CKJ, Nair CMG. Experimental infection of animals with influenza virus types A and B. Bull World Health Org. 1972;47:461-3.

13. Said AW, Usui T, Shinya K, Ono E, Ito T, Hikasa Y, et al. A sero-survey of subtype H3 influenza A virus infection in dogs and cats in Japan. J Vet Med Sci. 2011;73:541-4.

14. Serra VF, Stanzani G, Smith G, Otto CM. Point seroprevalence of canine influenza virus H3N8 in dogs participating in a flyball tournament in Pensylvania. J Am Vet Med Assoc. 2011;238:726-30.

15. Song D, Lee C, Kang B, Jung K, Oh T, Kim H, et al. Experimental infection of dogs with avian-origin canine influenza A virus (H3N2). Emerg Infect Dis. 2009;15:56-8.

16. Song D, Moon H, Jung K, Yeom M, Kim H, Hans S, et al. Association between nasal shedding and fever that influenza A (H3N2) induces in dogs. Virol J. 2011;8:1.

17. Taubenberger JK, Morens DM. Influenza: the once and future pandemic. Public Health Rep. 2010;125(Suppl 3):16-26.

18. Van Riel D, Munster VJ, de Wit E, Rimmelzwaan GF, Fouchir RA, Osterhaus AD, et al. Human and avian influenza viruses target different cells in the lower respiratory tract of humans and other mammalians. Am J Pathol. 2007;171:1215-23.

19. Yamanaka T, Nemoto M, Tsujimura K, Kondo T, Matsumura T. Interspecies transmission of equine influenza virus (H3N8) to dogs by close contact with experimentally infected horses. Vet Microbiol. 2009;139(3-4):351-5.

20. Webster RG, Shortridge KF, Kawaoka Y. Influenza: interspecies transmission and emergence of new pandemics. FEMS Immunol Med Microbiol. 1997;18:275-9.

Received: 12 December 2011

Accepted: 15 June 2012 